\title{
Recognising indigenous vegetables as potential contributors to livelihoods development: a case of two district municipalities in northern KwaZulu-Natal
}

Qwabe, Q.N. ${ }^{1}$, Zwane, E.M. ${ }^{2}$, Swanepoel, J.W. ${ }^{3}$

Corresponding author: Qwabe Q.N. Email: QwabeQN@ufs.ac.za

\begin{abstract}
South Africa is a food sufficient country. Native South Africans, however, continue to suffer from food insecurity at a household level, even under contemporary democratic leadership. Influenced by the COVID-19 pandemic, the study was conducted to determine the role of indigenous vegetables in rural livelihoods in the two selected district municipalities of northern KwaZulu-Natal, namely iLembe District Municipality (IDM) and the King Cetshwayo District Municipality (KCDM). A purposive sample which consisted of 130 participants $(n=130)$ was drawn, and data were analysed descriptively using Microsoft Excel Software. Our findings point in the direction that indigenous vegetables have the potential to contribute to livelihoods development. It was also found that these vegetables can thrive under diverse climatic conditions, including both irrigated and rainfed areas. This is especially important in a country like South Africa which faces major challenges of water scarcity and household food insecurity. Most household heads in the study were unemployed and relied on government monetary incentives for survival. It is concluded that there is a need to include these indigenous crops as part of the main discussions in the food discourse and to recognise them as a tool to enhance livelihood development.
\end{abstract}

Keywords: Indigenous vegetables; livelihoods; rural communities; socioeconomic status

\section{INTRODUCTION}

Following the transition to democracy in 1994, many South Africans hoped that the legacy of the apartheid regime would remain in the country's archives and present a socioeconomic transformation. Twenty-six years later, the previously disadvantaged continue

\footnotetext{
${ }^{1}$ Lecturer, Centre for Sustainable Agriculture, Faculty of Natural and Agricultural Sciences, University of the Free State Bloemfontein, South Africa. Email: QwabeQN@ufs.ac.za. ORCID link: https://orcid.org/0000-0002-0406-7339.

${ }^{2}$ Head of Department, Department of Agricultural Economics and Animal Production, School of Agriculture, University of Limpopo. South Africa. Email: zwanefrank@gmail.com or elliot.zwane@ul.ac.za, ORCID link: https://orcid.org/0000-0002-5933-2910.

${ }^{3}$ Senior Lecturer, Centre for Sustainable Agriculture, Faculty of Natural and Agricultural Sciences, University of the Free State, Bloemfontein, South Africa. Email: SwanepoelJW@ufs.ac.za, ORCID link: https://orcid.org/0000-0002-0812-2657.
} 
to suffer from the remnants of systematic segregation, which led to the persistent socioeconomic challenges of unemployment, poverty, and inequality (Masipa, 2018). This is despite South Africa's projected goal of eliminating poverty and reducing inequality as proclaimed in the National Development Plan (NDP) (NPC, 2012). Considerable strides have been made to enhance the well-being of the citizens, including the implementation of pro-poor policies and programmes that have been introduced since 1994 (DPME, 2014), such as:

(i) the social grant programme;

(ii) no-fee schools for the poor;

(iii) government-funded school lunches;

(iv) primary healthcare services;

(v) low-income housing subsidy for the poor;

(vi) free basic water and electricity to the poor;

(vii) agricultural support programmes for rural households engaged in subsistence farming; and

(viii) public employment schemes, which have created more than 4 million work opportunities since 1994.

Since the first registered case of the novel Coronavirus in South Africa, this virus has been found to be more and more severe as new variants occur. On the $5^{\text {th }}$ of March 2020, the South African National Institute of Communicable Diseases (NICD) reported its first confirmed case of the novel Coronavirus, which has gained popularity as COVID-19 (Staunton, Swanepoel and Labuschaigne, 2020). Six days later, on the $11^{\text {th }}$ of March 2020, this announcement was followed by the World Health Organization's (WHO) declaration that the COVID-19 outbreak was a global crisis that needed a swift response (Jebril, 2020). This virus has been more severe among vulnerable groups, including the elderly and those with underlying health conditions such as hypertension, cardiac disease, lung disease, renal disease, diabetes, active tuberculosis, malignancy, obesity, and HIV (Mendelson and Cohen, 2020).

The most recent report by Statistics South Africa (SSA) on the status of elderly people in South Africa indicates that more than half of the South African households are headed by the unemployed elderly who are above the age of 60, and most are female (SSA, 2014). These findings have also been corroborated by scholars, more especially those whose interest is in the demographic and socio-economic positioning of rural communities (Schatz, Madhavan, Collinson, Go'mez-Olivé and Ralston, 2015; Madhavan, Schatz, Gómes-Olivé and Collinson, 2017). South Africa is one of the countries most severely affected by the COVID-19 pandemic, and with existing socio-economic inequalities, poor communities remain the most vulnerable in many facets insofar as livelihoods development can be defined. In response to some of the barriers that hinder the sustainability of people's livelihoods, the harnessing of indigenous vegetables as a strategy for livelihoods development should be promoted. We borrow the Ministry of 
Agriculture's definition of indigenous food crops and define indigenous vegetables as food crops (grains, tubers and leafy-vegetables) that have their origin in South Africa, some of which have been introduced to the country and are now recognised as naturalised or traditional crops (DAFF, 2013). We present this article in two parts. In part I, we start by charting the living conditions of rural communities in South Africa to provide context about the socio-economic situation in these communities. Part II presents primary data and justifies the need to recognise indigenous vegetables.

\section{STUDY OBJECTIVES}

This study is anchored on the following objectives:

(a) to provide context about the socio-economic status of rural communities;

(b) to discuss the Nexus between COVID-19 and the rural economy; and

(c) to highlight the significance of indigenous vegetables on livelihoods development.

\section{UNDERSTANDING LIVING CONDITIONS OF RURAL COMMUNITIES}

The living conditions in rural communities are an important factor in relation to indigenous vegetable production in South Africa. Although only two district municipal areas in KZN were investigated, the results can be extrapolated to other rural parts of the country that have similar characteristics.

\subsection{General overview of South African rural communities}

South Africa faces a triple challenge of inequality, unemployment, and poverty, all of which are arguably the remnants of the apartheid regime (Cleland, 2017). Almost two decades after South Africa transitioned to democracy, the NDP was developed, which sought to eliminate poverty and reduce inequality by 2030 through growing an inclusive economy and improving social, technical, and physical infrastructure. To date, rural communities of South Africa face numerous challenges that are unique to their environment, as outlined below:

- The levels of deprivation continue to be a barrier against accessing health care services among poor rural communities (Gaedei and Versteegii, 2011).

- The poor primary and secondary education resulting from a multiplex of socioeconomic challenges (Du Plessis and Mestry, 2019).

- The South African rural regions are characterised by a constantly declining economy because of poor service delivery, high levels of unemployment, underutilisation of resources, a decrease in agricultural activities, poor transport routes and maintenance of infrastructure, lack of essential community facilities, and a lack of spatial and land use planning (Meyer, 2014).

- Rural areas mostly comprise poor, female-headed households (Cheteni, Khamfula and Mah, 2019). 
- Social problems, such as homelessness, manifest in areas where there is poor housing (Lorraine and Molapo, 2014).

\subsection{Nexus between COVID-19 and the rural economy}

The outbreak of the Coronavirus has disoriented the way of living across the world, with over 5.9 million people to date who have succumbed to the virus. An investigation by Paul, Nath, Mahanta, Sultana, Kayes, Noon and Paul (2020) indicates that the severe impact of COVID-19 has mostly been observed among frontline workers, farmers and day labourers. In South Africa, rural livelihoods are anchored in agriculture, with rural people mostly participating in the informal sector. However, due to the pandemic that has come with national lockdowns, many job losses have been experienced, with the informal sector being the worst affected (Tswanya, 2020). The relationship between the COVID19 pandemic and sustainability in the context of rural livelihoods has self-evidently proved that the situation is complex and thus requires immediate attention.For this reason, Part II justifies a need to recognise indigenous vegetables as one of the potential solutions to the existing socio-economic challenges which contribute to unsustainable livelihoods.

\section{RESEARCH METHODOLOGY}

\subsection{Study area}

The study focused on rural communities from two district municipalities within the northern region of KwaZulu-Natal (KZN), namely Ilembe District Municipality (IDM) and the King Cetshwayo District Municipality (KCDM). In 2017, most rural KZN households were classified beneath the low-income category, where the annual income ranged between R0 and R54 000. (Treasury, 2017). Consequently, farming is a major contributor to household food security.

\subsection{Sampling procedure, data collection and analysis}

To meet the selection criteria, participants had to be geographically located within the rural areas of the selected municipalities (IDM and KCDM), previously involved in farming, and household heads. With the help of agricultural extension officers who were the direct link to the participants, a total sample of 130 participants $(n=130)$ were selected from both municipalities. Each municipality was represented by 65 participants.

As a means of obtaining data related to the broad aim of the study, a quantitative approach was employed, and primary data were collected using a survey. The survey was in the form of a questionnaire, and it consisted of closed-ended questions, which were distributed to study participants with the assistance of extension officers from the two selected communities. Participants in the study had varying proficiency levels in either English or Zulu, while levels of education also ranged from little formal training to those with tertiary education qualifications. For this reason, the study material was prepared in both English and Zulu. This data collection technique was convenient as the study was 
conducted during alert level 3 of the national lockdown in response to the pandemic. The questionnaires which were delivered to the study participants gave an indication of their perceptions regarding indigenous vegetables and how these could be used as an essential source of livelihoods development. Data was analysed using the Microsoft Excel (MS Excel) Software for descriptive statistics. According to Divisi, Di Leonardo, Zaccagna and Crisci (2017), Microsoft Excel simplifies the processing and management of data using spreadsheets, which was also undertaken during the analysis of this study. The findings are presented descriptively using graphs and tables.

\section{RESULTS AND DISCUSSION}

\subsection{Profiling the socioeconomic status of Ilembe and King Cetshwayo District Municipalities}

The socio-economic profile of the two selected district municipalities includes the number of household members, gender, marital, age, education, employment status of the household head, and religion. The findings of this study are solely based on the 130 responses recorded. For comprehensive socio-economic profiling, we recommended that readers familiarise themselves with the latest recorded findings from Statistics South Africa (SSA), obtainable from the following website: http://www.statssa.gov.za/. The analysis of the socio-economic status forms an integral part of this research since the study is rooted in livelihoods development. The socio-economic profile of the participants is indicated in Table 1 below.

While the demographic findings do not appear to have an uncommon bearing, it is worth noting that households mostly comprise 6-10 family members in both district municipalities. A report by Statistics South Africa indicates that the food poverty line currently stands at R585.00 per person monthly (SSA, 2020). Since most of the participants indicated that they are unemployed and mostly depend on government grants, a household that comprises ten household members needs at least R5850.00 to spend on food alone. In South Africa, to qualify for an old-age pension, one must be 60 years or older. The age distribution of the household head in Table 1 shows that most of the participants do not qualify for this grant as household heads range between ages 20-59 years in both IDM $(58.5 \%)$ and KCDM (73.9\%). However, some households get relief from the child support grant of R460.00 for children under 18 years. 
TABLE 1: Demographic Data

\begin{tabular}{|c|c|c|c|c|}
\hline \multirow[b]{2}{*}{ Variables } & \multicolumn{2}{|l|}{ IDM } & \multicolumn{2}{|l|}{ KCDM } \\
\hline & $\begin{array}{l}\text { No. of } \\
\text { Participants }\end{array}$ & $\%$ & $\begin{array}{l}\text { No. of } \\
\text { Participants }\end{array}$ & $\begin{array}{l}\text { KCD } \\
(\%)\end{array}$ \\
\hline \multicolumn{5}{|l|}{ Household members } \\
\hline$<5$ & 22 & 33.9 & 14 & 21.5 \\
\hline $6-10$ & 32 & 49.2 & 37 & 56.9 \\
\hline $11-15$ & 10 & 15.4 & 10 & 15.4 \\
\hline$>16$ & 1 & 1.5 & 4 & 6.2 \\
\hline \multicolumn{5}{|c|}{ Gender of household head } \\
\hline Male & 40 & 61.5 & 26 & 40.0 \\
\hline Female & 25 & 38.5 & 39 & 60.0 \\
\hline \multicolumn{5}{|l|}{ Marital status } \\
\hline Unmarried & 15 & 23.1 & 33 & 50.8 \\
\hline Married & 36 & 55.4 & 18 & 27.7 \\
\hline Divorced & - & - & - & - \\
\hline Widow/er & 14 & 21.5 & 14 & 21.5 \\
\hline \multicolumn{5}{|l|}{ Age of household head } \\
\hline $20-39$ & 14 & 21.6 & 23 & 35.4 \\
\hline $40-59$ & 24 & 36.9 & 25 & 38.5 \\
\hline $60-79$ & 27 & 41.5 & 16 & 24.6 \\
\hline $80-100$ & - & - & 1 & 1.5 \\
\hline \multicolumn{5}{|c|}{ Educational status of household head } \\
\hline Primary & 26 & 40.0 & 18 & 27.7 \\
\hline Secondary & 22 & 33.8 & 30 & 46.2 \\
\hline Tertiary & 5 & 7.7 & 9 & 13.8 \\
\hline Never went to school & 12 & 18.5 & 8 & 12.3 \\
\hline \multicolumn{5}{|l|}{ Employment status } \\
\hline Employed & 4 & 6.2 & 10 & 15.4 \\
\hline Self-employed & 16 & 24.6 & 16 & 24.6 \\
\hline Unemployed & 45 & 69.2 & 39 & 60.0 \\
\hline \multicolumn{5}{|l|}{ Religion } \\
\hline Christian & 42 & 64.6 & 52 & 80 \\
\hline Non-Christian & 23 & 35.4 & 13 & 20 \\
\hline
\end{tabular}

It should be noted, however, that this amount is also below the food poverty line, as documented by SSA. The study indicated that indigenous vegetables were highly preferred by people residing in the cities and townships to whom the rural farmers sold some of their produce (Figure 1). It is assumed that since people relocate from rural areas to cities as a result of urbanisation, they still desire to consume their indigenous foods which form a great part of their cultural background. Consequently, they resort to purchasing these products from their rural counterparts. This suggests that the production 
of indigenous vegetables does not only contribute towards household food security but also contributes to uplifting the rural economy. For this reason, the role of indigenous vegetables in household food security should not be overlooked but treated with a high degree of importance. There are dynamics on marital status that were recorded for the two municipal areas. IDM mostly comprises married male-headed households, while $\mathrm{KCDM}$ is mostly unmarried female household heads.

Figure 2 illustrates the preferred vegetable products between these two district municipalities. It can be argued that IDM farmers mostly produce and utilise indigenous vegetables because males, who constitute most household heads in IDM, are generally more inclined to value their culture, which is also reflected in the kinds of foods that are consumed within the household. On the contrary, KCDM household heads are mostly female and while Table 2 indicates that indigenous vegetables are the most preferred, their non-indigenous vegetable counterparts (exotic vegetables) are also highly preferred. The reason for the preference of non-indigenous vegetables is because they do not take long to grow and are quicker to prepare in comparison to indigenous vegetables, which are believed to take longer to cook (Jansen van Rensburg, van Averbeke, Slabbert, Faber, van Jaarsveld, van Heerden, Wenhold and Oelofse, 2007). In other words, nonindigenous vegetables bring convenience to female-headed households since they have the responsibility for everything that happens within the household and additionally, their religious activities.

\subsection{Preference of vegetables}

Participants were asked to indicate reasons for their preference of vegetables. Their responses are indicated in Figure 1.

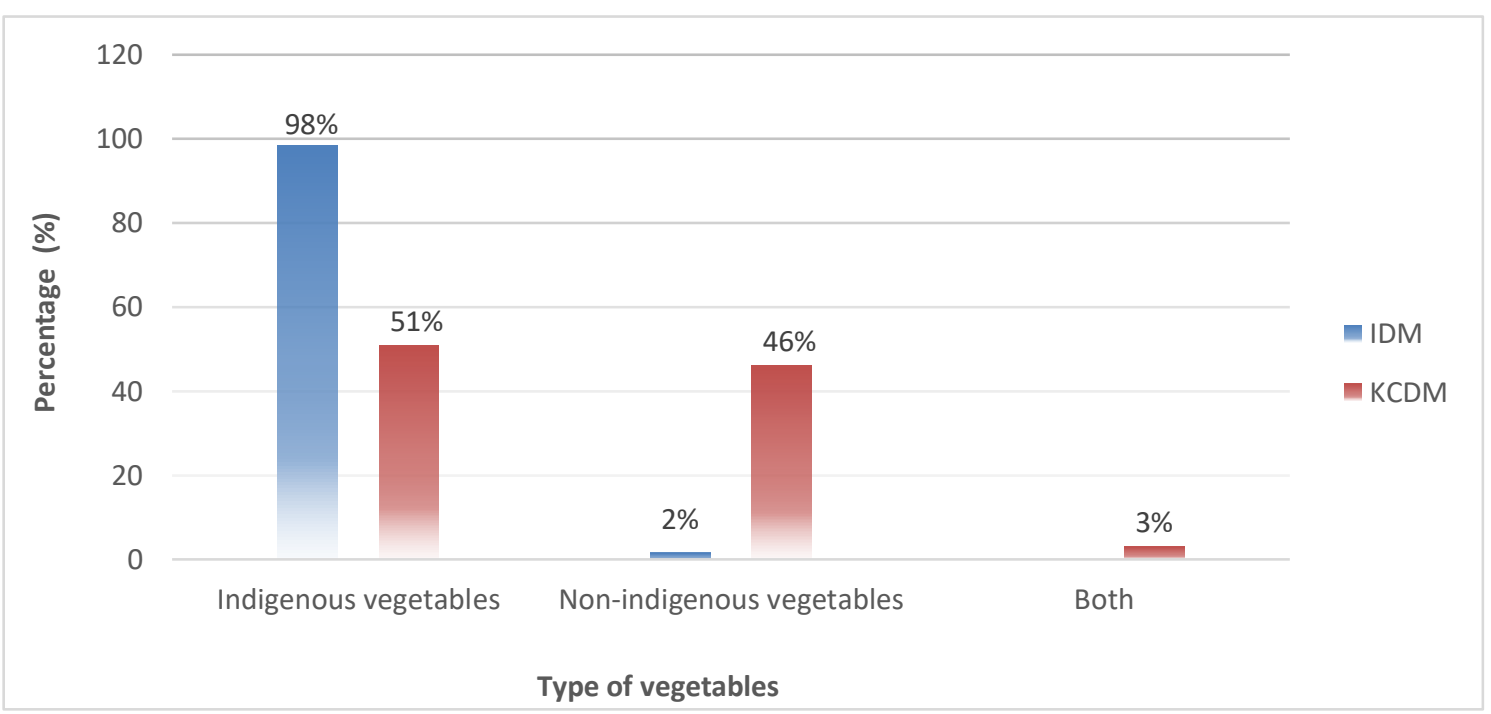

FIGURE 1: Distribution according to preferred types of vegetables

All the study participants indicated that they utilised indigenous vegetables, both cultivated and those that occur naturally in the wild. This finding agrees with Vorster 
(2007), who found that in three district communities of Limpopo Province, people mostly preferred indigenous vegetables in their diet as they were perceived to be more nutritious. A comparison between indigenous vegetables and their non-indigenous counterparts was made to determine which of the two groups were perceived to be the most preferred in the communities. In both municipalities, it was discovered that the most preferred types of vegetable products were the indigenous vegetables. This was corroborated by $51 \%$ of the participants from KCDM and 98.5\% from IDM. Some of the reasons for the preference towards these vegetables is because they form part of the people's heritage and culture and are believed to have health benefits that outweigh the conventional nonindigenous vegetable varieties when consumed, since they are mostly produced organically. However, a relatively smaller group from both municipalities indicated that they perceived non-indigenous vegetables most preferred. Indigenous vegetables originated in these locations; therefore, they are better adapted to climate conditions and have a higher chance of being more nutritious than non-indigenous vegetables.

\subsection{Reason for preference of vegetables}

Participants were asked to indicate reasons for their preference of indigenous vegetables. Their responses are indicated in Figure 2.

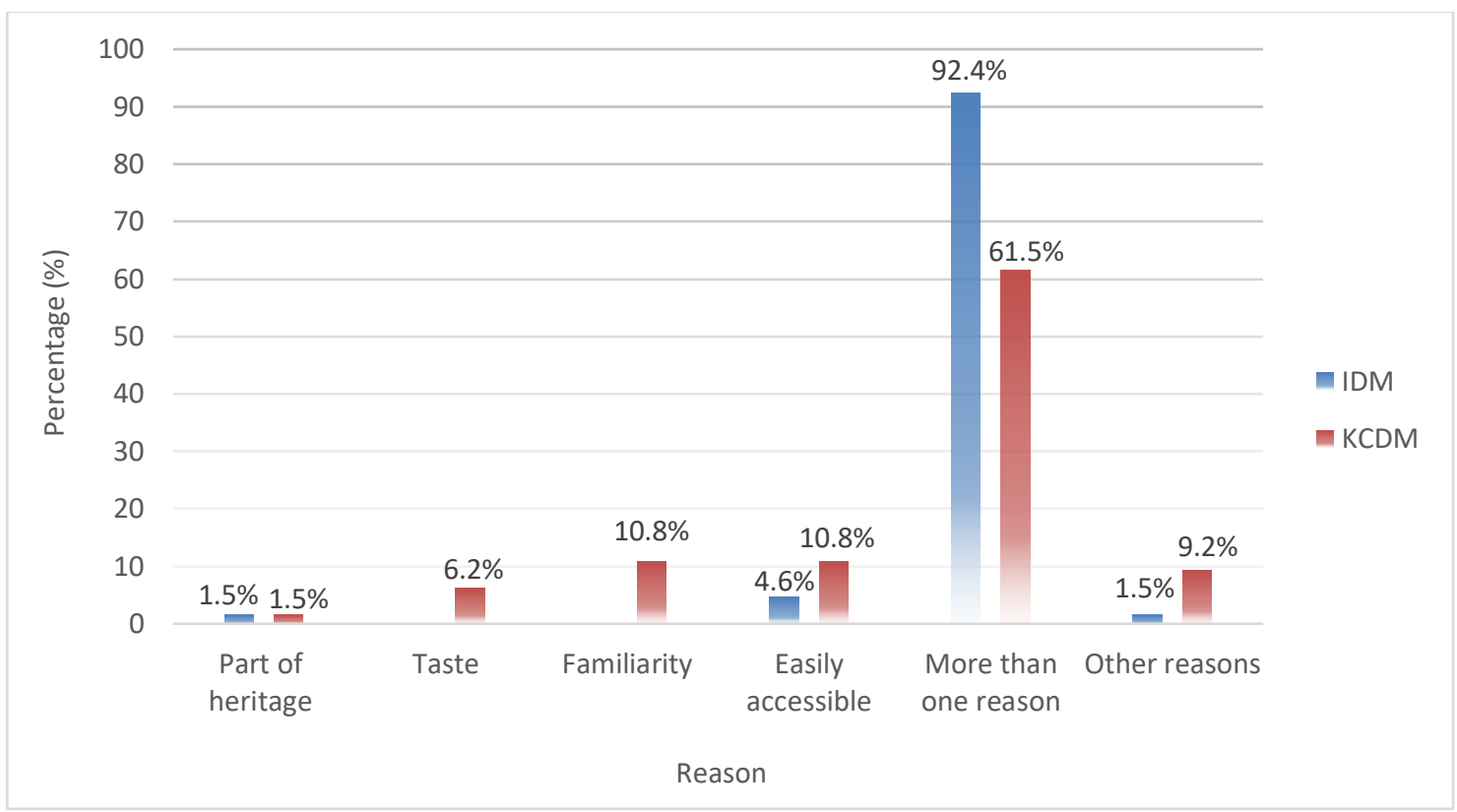

\section{FIGURE 2: Distribution according to reasons for preference}

The illustration in Figure 2 indicates the rationale behind the preference of indigenous vegetables over their non-indigenous counterparts in the selected districts as, (i) Indigenous vegetables being part of people's cultural heritage, (ii) their preferred taste, (iii) familiarity with these vegetables, (iv) easy accessibility, and (v) perceived health benefits. In South Africa, cultural heritage is one of the most appreciated ethnic norms. To support this, we refer to Heritage Day; a public holiday celebrated annually on the $24^{\text {th }}$ 
of September. On this day, rituals, language, and food are some of the ceremonial objects that are embraced. It is also true that since indigenous vegetables are easily accessible for the participants, it is easier for them to become familiar with these vegetable products and value their taste. Vorster (2007) asserts that the health benefits associated with the consumption of indigenous vegetables is one of the reasons behind their preference. The findings of this study agree with the latter claim as participants indicated that they mostly preferred these vegetables because of their health benefits.

\subsection{Environment conducive to indigenous vegetables}

Participants were asked to indicate which environment is conducive to the growth of indigenous vegetables. Their responses are indicated in Figure 3.

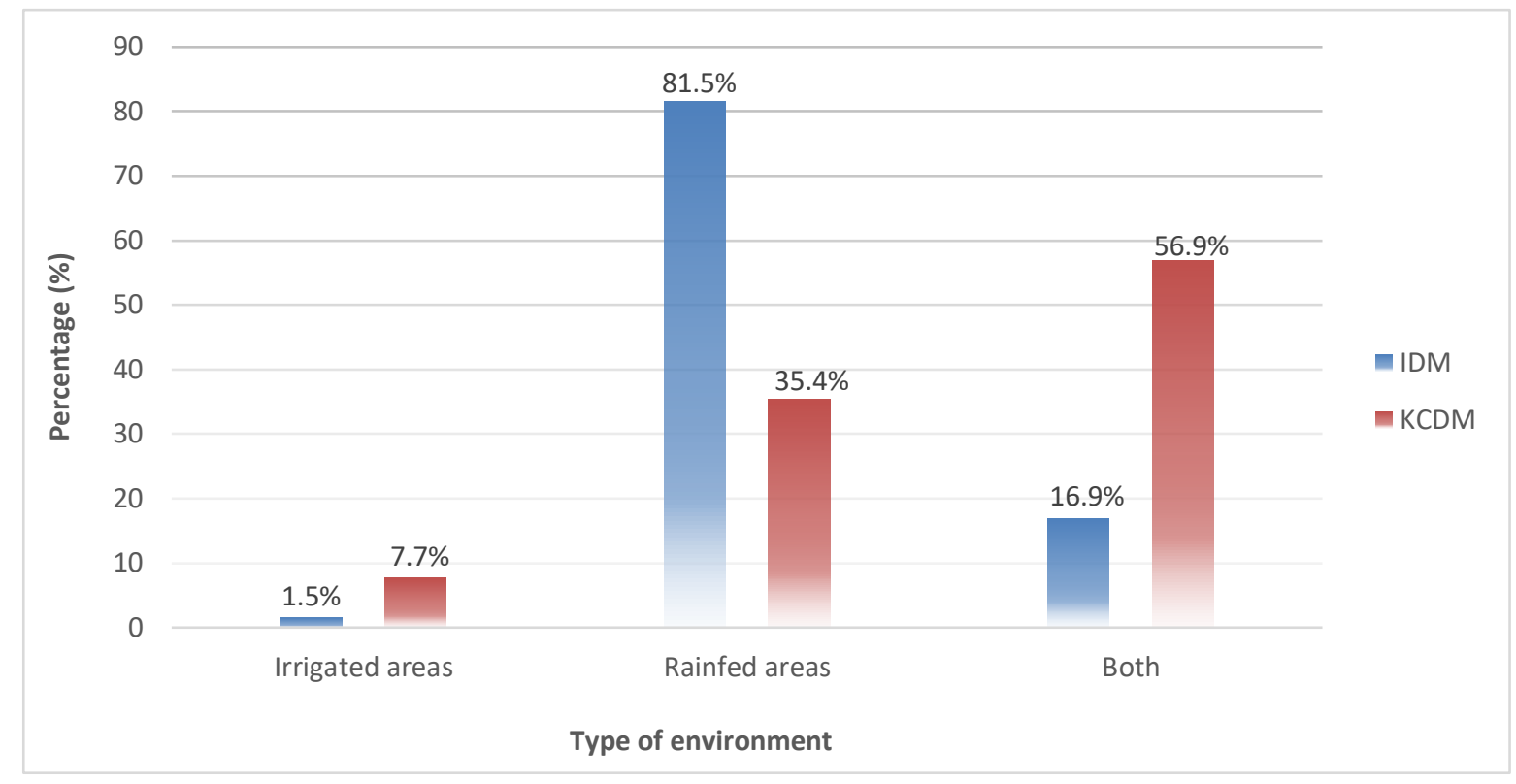

\section{FIGURE 3: Type of environment conducive to indigenous vegetables}

Most participants from KCDM (81.5\%) indicated that the indigenous vegetables they utilise mostly thrive in rainfed areas with good precipitation. Examples of these include the likes of taro and sweet potatoes (tubers), cowpeas and jugo beans (grains), as well as amaranth and blackjack (leafy vegetables). On the contrary, $73.8 \%$ of the participants indicated that indigenous vegetables thrive both under irrigated and rainfed conditions. These findings agree with Slabbert, Spreeth and Kruger (2004), who screened different germplasms of indigenous vegetables for drought tolerance and concluded that indigenous vegetables tolerate arid-land conditions.

\subsection{Challenges associated with the production of indigenous vegetables}

Ezeanya-Esiobu (2018) points out lack of information, the dearth of research and development and the safeguarding of seeds as some of the challenges associated with indigenous vegetable production. On this basis, the study participants were asked to 
indicate the underlying challenges when producing indigenous vegetables, and their responses are recorded in Table 2.

TABLE 2: Challenges associated with the production of indigenous vegetables

\begin{tabular}{|l|l|l|l|l|}
\hline & \multicolumn{2}{l|}{ KDM } & \multicolumn{2}{l|}{} \\
\hline & $\begin{array}{l}\text { No. of } \\
\text { Participants }\end{array}$ & $\begin{array}{l}\text { Percentage } \\
(\%)\end{array}$ & $\begin{array}{l}\text { No. of } \\
\text { Participants }\end{array}$ & $\begin{array}{l}\text { Percentage } \\
(\%)\end{array}$ \\
\hline $\begin{array}{l}\text { Information by CDWs } \\
\text { (eg., extension services) }\end{array}$ & & & 56 & 87 \\
\hline Provided (positive) & 64 & 98.5 & 9 & 13 \\
\hline Not provided (negative) & 1 & 1.5 & & \\
\hline $\begin{array}{l}\text { Effect of varying } \\
\text { climatic conditions }\end{array}$ & & & 49 & 75 \\
\hline Affect (negative) & 10 & 15 & & 25 \\
\hline Does not affect (positive) & 55 & 85 & & \\
\hline $\begin{array}{l}\text { Youth perceptions of } \\
\text { indigenous vegetables }\end{array}$ & & & 43 & 66 \\
\hline Positive & 62 & 95 & 22 & 34 \\
\hline Negative & 3 & 5 & & \\
\hline
\end{tabular}

According to the data presented in Table 2, three challenges were identified from the participants. These challenges include the knowledge that community development workers possess about indigenous vegetables, the effect of climate, and the perception of the youth on indigenous vegetables. Approximately 98.5\% of participants from IDM and $87 \%$ from KCDM indicated that community development workers (CDWs), such as social and agricultural extension services, provide information about the importance of indigenous vegetables. This is critical as extension services are the most influential drivers of transformation in rural farming communities. In support of this, Maulu, Hasimuna, Mutale, Mphande and Siankwilimba (2021) noted that through the use of appropriate approaches, rural extension programmes have the potential to provide a sustainable solution to poverty.

It is common knowledge that one of the challenges that farmers face globally is climate change. In the KZN Region, there are three climate zones varying from tropical, subtropical to temperate (Motsa, Modi and Mabhaudhi, 2015). IDM lies in the subtropical part of the province (COGTA, 2017), while KCDM is on the humid tropical side (EOH Coastal and Environmental Services, 2018). When asked about the effect of climate on the production and development of indigenous crops, $85 \%$ of IDM respondents indicated that the varying climatic conditions hindered neither the growth nor the development of these crops. On the contrary, $75 \%$ of the participants from KCDM indicated that the 
varying climatic conditions do affect the growth of indigenous vegetables. These findings indicate that indigenous vegetables are better adapted to local climatic conditions.

Akinola, Mabhaudhi, De Bruin and Rusch (2020) assert that indigenous and traditional food crops (ITFCs) have been a reliable source of food for communities over millenia but have been portrayed as a poor man's food by colonisers. In South Africa, the stigma against indigenous crops has been driven by researchers and agricultural extension services who have been referring to them as 'weeds' since the 1960s (Ineke, Jansen van Rensburg, Zijl and Sonja, 2007). While this may be true in some areas, our findings do not concur with this assertion. Most (95\%) of the study participants from IDM held the view that the younger generation recognises the value of indigenous crops. Similarly, $66 \%$ of KCDM participants indicated that based on their observation, the younger generation does see the value of indigenous crops. However, more research that focuses on youth perceptions and indigenous vegetables is still needed.

\section{CONCLUSION AND RECOMMENDATIONS}

This study has provided insight into the socioeconomic status of rural residents from Ilembe District Municipality (IDM) and the King Cetshwayo District Municipality (KCDM). The findings indicate that a significant number of households are headed by unemployed individuals who mostly have more than five dependants in their households. Considering the current times in which both the global and national economies seem to be in a constant decline due tomarket dynamics and unprecedented shocks such as the COVID-19 pandemic, third-world countries are the worst affected. This is especially true for South Africa, where the triple threat of unemployment, inequality, and poverty is rife. Citizens in the marginal parts of the country usually suffer the most due to socioeconomic challenges such as illiteracy and high unemployment rates.

However, it is worth noting that as times change and teachings point towards cancelling indigenous practices, people are also changing their indigenous ways of doing things. The findings also indicate that these indigenous vegetables have a critical role in response to the prevailing socio-economic challenges in regions like the IDM and KCDM. Anchoring this on the positive response to the preference of indigenous vegetables, it can be suggested that these have the potential to contribute to household food security. This is especially important at such a time when the economy is in constant decline. Based on the findings, the study recommends that indigenous vegetables as a livelihoods development strategy should be considered and appreciated by society. Their socioeconomic importance qualifies them to form part of the narrative in the food discourse arena. In addition to this, more research is required to investigate the nutritional benefits of indigenous vegetables as well as methods to improve their productivity rate. 


\section{REFERENCES}

AKINOLA, R., MABHAUDHI, L., DE BRUIN, F. AND RUSCH, L. 2020. A review of indigenous food crops in Africa and the implications for more sustainable and healthy food systems. Sustainability., (12): 1-30.

CHETENI, P., KHAMFULA, Y. AND MAH, G. 2019. Gender and poverty in South African rural areas. Cogent Soc. Sci., (5): 1-19.

CLELAND, J. 2017. Population growth, employment, and livelihoods: The triple challenge. J. Demogr. Econ., (83): 51-61.

COGTA. 2017. Integrated Development Plan 2015/16 Review. Ilembe District Municipality. Retrieved January 2021, https://ilembe.gov.za/wpcontent/uploads/2020/04/Final-IDP-Review-2015-16-29-May-2015.pdf

DAFF. 2013. Most common indigenous food crops of South Africa. Pretoria: Directorate: Plant Production.

DIVISI, D., DI LEONARDO, G., ZACCAGNA, G. AND CRISCI, R. 2017. Basic statistics with Microsoft Excel: a review. J. Thorac. Dis,, 9(6): 1734-1740.

DPME. 2014. Twenty year review South Africa: 1994-2014. Retrieved January 2021, https://www.gov.za/sites/default/files/gcis_document/201409/20yearreview.pdf

DU PLESSIS, P. AND MESTRY, R. 2019. Teachers for rural schools - a challenge for South Africa. S. Afr. J. Educ., 39(1): S1-S9.

EOH COASTAL AND ENVIRONMENTAL SERVICES. 2018. Environmental Management Framework. Richards Bay: King Cetshwayo District Municipality.

EZEANYA-ESIOBU, C. 2018. Indigenous Vegetable Production and the Economic Empowerment of Rural Women in Africa: Reality, Prospects, and Challenges in Rwanda. IK: Other Ways of Knowing, (4): 133-156.

FAO. 1996. World Food Summit: Declaration on World Food Security. Rome: Italy.

GAEDEI, B. AND VERSTEEGII, M. 2011. The state of the right to health in rural South Africa. S Afr Med., (9): 99-106.

INEKE, V., JANSEN VAN RENSBURG, W., ZIJL, V. AND SONJA, L. 2007. ReCreating Awareness of Traditional Leafy Vegetables in Communities. African J. Food, Agric. Nutr. Dev., (7): 1-3.

JANSEN VAN RENSBURG, W., VAN AVERBEKE, W., SLABBERT, R., FABER, M., VAN JAARSVELD, P., VAN HEERDEN, I., . . . OELOFSE, A. 2007. African leafy vegetables in South Africa. Water SA, 33(3): 317-326.

JEBRIL, N. 2020. World Health Organization declared a pandemic public health menace: a systematic review of the coronavirus disease 2019 "COVID-19". Int. J. Psychosoc., 24(9): 9160-9166.

LORRAINE, M. AND MOLAPO, R. 2014. South Africa's Challenges of Realising her Socio-Economic Rights. Mediterr. J. Soc. Sci., 5(27): 900-907. 
MADHAVAN, S., SCHATZ, E., GÓMES-OLIVÉ, F. AND COLlinSON, M. 2017. Social Positioning of Older Persons in Rural South Africa: Change or Stability? J. South. Afr. Stud., 43(6): 1293-1307.

MASIPA, T. 2018. South Africa's Transition to democracy and democratic consolidation: A reflection on socio-economic challenges. J. Public Aff., (18) 1-6.

MAULU, S., HASIMUNA, O., MUTALE, B., MPHANDE, J AND SIANKWILIMBA, E. 2021. Enhancing the role of rural agricultural extension programs in poverty alleviation: A review. Cogent food agric., 7(1). DOI: https://doi.org/10.1080/23311932.2021.1886663.

MENDELSON, M. AND COHEN, C. 2020. The COVID-19 crisis in South Africa: Protecting the vulnerable. S. Afr. Med., 110(9): 825-826.

MEYER, D. 2014. Exploration of Solutions for Revitalisation of Rural Areas in South Africa. Mediterr. J. Soc. Sci., 5(4): 613-625.

MOTSA, N., MODI, A. AND MABHAUDHI, T. (2015). Sweet potato (Ipomoea batatas L.) as a drought tolerant and food security crop. S. Afr. J. Sci., 111(11/12): 1-8.

NPC. 2012. National Development Plan. Pretoria: National Planning Commission, Office of the Presidency.

PAUl, A., NATH, T., MAHANTA, J., SULTANA, N., KAYES, A., NOON, S., . . . PAUL, S. 2020. Psychological and Livelihood Impacts of COVID-19 on Bangladesh Lower Income People. Asia Pac J Public Health, 1-9.

SCHATZ, E., MADHAVAN, S., COLLINSON, M., GO’MEZ-OLIVE', F. AND RALSTON, M. 2015. Dependent or Productive? A New Approach to Understanding the Social Positioning of Older South Africans Through Living Arrangements. Res. Aging., 37(6): 581-605.

SLABBERT, R., SPREETH, M. AND KRUGER, G. 2004. Drought tolerance, traditional crops and biotechnology: breeding towards sustainable development. S. Afr. J. Bot., 70(1): 116-123.

SSA. 2014. Census 2011: Profile of older persons in South Africa. Pretoria: Statistics South Africa. Retrieved January 2021, https://www.statssa.gov.za/publications/Report-03-01-60/Report-03-01602011.pdf

STAUNTON, C., SWANEPOEL, C. AND LABUSCHAIGNE, M. 2020. Between a rock and a hard place: COVID-19 and South Africa's response. J. Law Biosci., 7(1): $1-12$.

TREASURY, K. 2017. Socio-economic review and outlook 2017/2018. Provincial treasury. Pietermaritzburg. Retrieved January 2021, https://www.kzntreasury.gov.za/ResourceCenter/Documents\%20\%20Fiscal\%20 Resource\%20Management/SERO_Final_28\%20Feb\%202017.pdf 
TSWANYA, T. 2020. So. Africa: Three million South Africans have lost their jobs as a result of the Covid-19 pandemic, women most affected. Johannesburg, Gauteng, South Africa. Retrieved January 2021, https://www.businesshumanrights.org/en/latest-news/so-africa-three-million-south-africans-have-losttheir-jobs-as-a-result-of-the-covid-19-pandemic-women-most-affected/

VORSTER, H. 2007. The role and production of traditional leafy vegetables in three rural communities in South Africa. University of Pretoria. 